\title{
TJPS-92063-Original Article INVESTIGATION OF PERIPHERAL ANALGESIC ACTIVITY OF OXICAMS AND ITS COMPOSITION WITH CAFFEINE
}

Anna Syrova ${ }^{1}$, Larisa Lukyanova ${ }^{1}$, Svetlana Kozub $^{1}$, Oksana Zavada $^{1}$, Olga Levashova ${ }^{1}$, Viktor Shaposhnik ${ }^{2}$

${ }^{1}$ Kharkiv National Medical University, Medical and Bioorganic Chemistry Department, Kharkiv, Ukraine

${ }^{2}$ Kharkiv National Medical University, $6^{\text {th }}$ year student of II medical faculty, Kharkiv, Ukraine

Objective: Therapy of pain syndromes involves exposure to its source, receptors and peripheral fibers. Treatment of acute pain and inflammation involves the use of non-steroidal anti-inflammatory drugs (NSAIDs) and non-narcotic analgesics (NNA). An alternative to obsolete analgesics is combined compositions. Analysis of experimental results clearly indicates that caffeine effectively enhances the analgesic activity of the peripheral origin when combined in a pharmaceutical composition.

The aim of the present study was to evaluate the peripheral analgesic activity of meloxicam, piroxicam and their pharmacological compositions with caffeine.

Materials and methods: The peripheral analgesic activity of piroxicam, meloxicam and their composition with caffeine was studied using the abdominal writhing test. This method used to induce pain of peripheral origin by intraperitoneal injection of $0.6 \%$ acetic acid solution. Investigated drugs, their composition and $3 \%$ starch mucilage were administrated 1 hour before the introduction of the algogene. The cumulative number of writhing responses induced by acetic acid were determined over next $20 \mathrm{~min}$.

Results: All investigated drugs showed a decrease of writhing in rats. Meloxicam and caffeine showed peripheral analgesic activity $63.6 \%$ and $64.5 \%$ respectively $(\mathrm{P}<0,05)$. The pharmaceutical composition of meloxicam and caffeine showed the analgesic potential $76.4 \%$. Thus, the caffeine potentiates the analgesic activity of meloxicam. Obtained results exceeded the corresponding value of diclofenac sodium (67.3\%) Conclusion: Analysis of experimental results clearly indicates that caffeine effectively enhances the analgesic activity of the peripheral analgesic action of meloxicam when combined in a pharmaceutical composition. Results can serve as foundation for development of new domestic combined drugs.

Key words: meloxicam, piroxicam, caffeine, pharmaceutical composition, analgesic activity.

\section{Giriş}

Ağrı sendromlarının tedavisi, ağrı kaynağına maruz kalmayı, reseptörleri ve periferal lifleri içermektedir. Akut ağrının ve yangının tedavisi, nonsteroidal antienflamatuar ilaçların (NSAID'ler) ve narkotik olmayan analjeziklerin (NNA) kullanımını içerir. Eski analjeziklere alternatif, kombine kompozisyonlardır. Deneysel sonuçların analizi, kafeinin, farmasötik bir bileşimde birleştirildiğinde, periferik orijinli analjezik aktivitesini etkin bir şekilde arttırdığını açıkça göstermektedir.

Bu çalışmanın amacı, meloksikam, piroksikam ve bunların kafeinle farmakolojik bileşimlerinin periferal analjezik aktivitesini değerlendirmektir.

Malzemeler ve yöntemler. Piroksikam, meloksikam ve bunların kafeinle yaptıkları bileşimlerinin periferal analjezik aktivitesi abdominal ağrı testi kullanılarak incelenmiştir. Bu yöntemde, periferik orijinli ağrının oluşturulmasında \% 0.6 'lık asetik asit çözeltisinin intraperitonel olarak enjekte edilmesiyle sağlanmıştır. İncelenen ilaçlar, bunłarın bileșimleri ve \% 3 nişasta müsilajı, algojenin verilmesinden 1 saat önce uygulandı. Asetik asit tarafindan indüklenen kümülatif ağrı cevapları, sonraki 20 dakika boyunca belirlenmiştir.

\section{Sonuçlar:}

İncelenen tüm ilaçlar, sıçanlarda ağrı azalması gösterdi. Meloksikamın ve kafeinin periferal analjezik aktiviteyi sırasıyla \% 63.6 ve \% 64.5 olarak bulunmuştur $(\mathrm{P}<0.05)$. Meloksikam ve kafeinin farmasötik bileşimi, \% 76.4'lük analjezik potansiyel göstermiştir. Bu nedenden dolayı kafein, meloksikamın analjezik aktivite potansiyellerini arttırmaktadır. Elde edilen sonuçlar diklofenak sodyumla elde edilen değerden (\% 67.3) fazladır. Sonuç: Deneysel sonuçların analizi, açıkça kafeinin, farmasötik bileşimde meloksikamla birleştirildiğinde meloksikamın periferal analjezik etkisini etkin bir şekilde arttırdığını göstermiştir. Sonuçlar yeni yerli kombine ilaçların geliştirilmesinde temel olabilir.

\section{INTRODUCTION}

Non-steroidal anti-inflammatory drugs (NSAIDs) and non-narcotic analgesics (NNA) are widely used for the treatment of inflammation and pain syndromes. The analysis of scientific literature has shown that polycomponent compositions are more effective than monopreparations in treating pain. Therefore, the development of new effective domestic multicomponent drugs with a minimum number of side effects is a very actual question ${ }^{1-4}$.

It is known that caffeine improves the analgesic effect of NNA. The mechanism of potentiation of analgesic effects is associated with an improvement of the NNA bioavailability in the combination with caffeine, and with the effect of caffeine on adenosine receptors (the so-called "purine analgesia") ${ }^{5-9}$. Study of the biological effects 
of caffeine and its pharmacological compositions showed a positive effect on the central nervous the system. Caffeine shows wide range of action: reduction of adenosine transmission, regulation of excitation processes in the cerebral cortex; in corresponding doses it enhances positive condition reflexes and increases motor activity ${ }^{10-}$ 13 .

The aim of our work was the experimental investigation of the peripheral analgesic activity of oxicams (meloxicam, piroxicam), caffeine and their pharmacological compositions.

\section{MATERIALS AND METHODS}

An experimental study of analgesic activity was conducted on laboratory animals - mature rats. The peripheral analgesic activity was studied by the changes in nociceptive reactions of rats. The comparative characteristic of the analgesic activity of meloxicam, caffeine and their pharmacological composition was studied using acetic acid induced abdominal writhing test. Writhes were caused by a single intraperitoneal injection of $0.6 \%$ acetic acid solution ( $1 \mathrm{ml}$ per $100 \mathrm{~g}$ of animal weight) in rats. The investigated drugs, their composition, and $3 \%$ starch solution were injected 1 hour before the algogen introduction. Then, the number of writhes was counted for 20 minutes ${ }^{14}$.

Animals were divided into 7 groups of 6 animals in each. $3 \%$ starch mucus ( $2 \mathrm{ml}$ per $200 \mathrm{~g}$ of rat's weight) was injected via gastric tube to intact animals of the first group. Experimental drugs and their composition were administrated to animals of groups 2-7 once via gastric tube: animals of the second group received piroxicam $(1.3 \mathrm{mg}$ per $1 \mathrm{~kg}$ of animal weight $), 3^{\text {rd }}-$ meloxicam $\left(0.6 \mathrm{mg}\right.$ per $1 \mathrm{~kg}$ of animal weight), $4^{\text {th }}$ - caffeine $(0.6 \mathrm{mg}$ per $1 \mathrm{~kg}$ of animal weight), $5^{\text {th }}$ - the composition of piroxicam ( $1.3 \mathrm{mg}$ per $1 \mathrm{~kg}$ of animal weight with caffeine $\left(0.6 \mathrm{mg}\right.$ per $1 \mathrm{~kg}$ of animal weight), $6^{\text {th }}$ - the composition of meloxicam $(0.6 \mathrm{mg}$ per $1 \mathrm{~kg}$ of animal weight) with caffeine $\left(0.6 \mathrm{mg}\right.$ per $1 \mathrm{~kg}$ of animal weight), $7^{\text {th }}$ - a reference drug - diclofenac sodium $(8 \mathrm{mg}$ per $1 \mathrm{~kg}$ of animal weight).

Analgesic activity was estimated by the ability of oxicams (meloxicam, piroxicam), caffeine, their

pharmacological composition and sodium diclofenac to reduce the number of writhes in experimental animal groups as compared to the control group and expressed in percentage by the formula:

$$
A A=\frac{C c-C e}{C c} \cdot 100 \%,
$$

where $\mathrm{AA}-$ analgesic activity \%;

$\mathrm{C}_{\mathrm{c}}-$ the average number of writhes in the control group;

$\mathrm{C}_{\mathrm{e}}$ - the average number of writhes in the experimental group [9-10].

In addition, the analgesic activity of oxicams, caffeine was compared with analgesic activity of their composition (meloxicam + caffeine and piroxicam + caffeine) and reference drug.

The study was carried out in accordance with the methodological recommendations of the State Pharmacological Center of the Ministry of Health of Ukrane ${ }^{14}$. Economical approach, bioethical rules and statistics requirements were considered when choosing number of animals and their allocation to the treatment groups.

The study was performed on laboratory animals from experimental biological clinic of KhNMU. Rats were housed under the strict norms of the storage, eare and feeding according to the principles of "European Convention for the Protection of Vertebrate Animals used for experimental and other scientific purposes" (Strasbourg, 1986) ${ }^{17}$ and the decision of the First national Congress on Bioethics (Kyiv, 2007) ${ }^{18}$. Room temperature was maintained at $23-25^{\circ} \mathrm{C}$, room lighting was $100 \mathrm{Lx}$, the animal cage - 20-40 Lx. The laboratory animals were housed for 1.5 months; acclimatization period -2 weeks; the main diet - vegetables, fodder beet; the source of water - settled tap water. Experiments were carried out in the morning, which according to the literature data corresponds to the dependence of the main pharmacological parameters and pharmacological activity of investigated drugs on circadian rhythms ${ }^{19-21}$.

Statistical calculations were performed by conventional methods using MS Excel and Stat Graphics Plus 2.1 programs $^{22}$

\section{RESULTS AND DISCUSSION}

A specific pain response was investigated by the method of chemical peritoneal irritation. There are several known methods of specific pain investigation: acetylcholine writhes and acetic acid-induced abdominal writhing tests. "Stretching" of animals in the acetylcholine writhes model caused by activation of the arachidonic acid metabolism with cyclooxygenase, resulting in increased synthesis of prostaglandins under the influence of acetylcholine. The mechanism of acetic acid-induced pathology activates the kinin-kallikrein system, prostaglandins, biogenic amines, leukotrienes, which are endogenous inflammatory mediators and contribute to the development of the abdominal muscle spasm, accompanied by the retraction of the hind paws and the back flexes. The effect of the investigated substances on the peripheral component of the nociceptive response was examined by the method of acetic acid abdominal writhing test, as the most informative.

In our previous studies, the central analgesic activity of caffeine in combination with piroxicam and meloxicam was studied in order to create a new medicinal composition. 
The results of experimental studies have shown that administration of piroxicam, meloxicam and caffeine monopreparations reduces number of writhes by 2, 2.6 and 2.8 times respectively compared to the control group and produce similar result as the reference drug (Fig. 1).

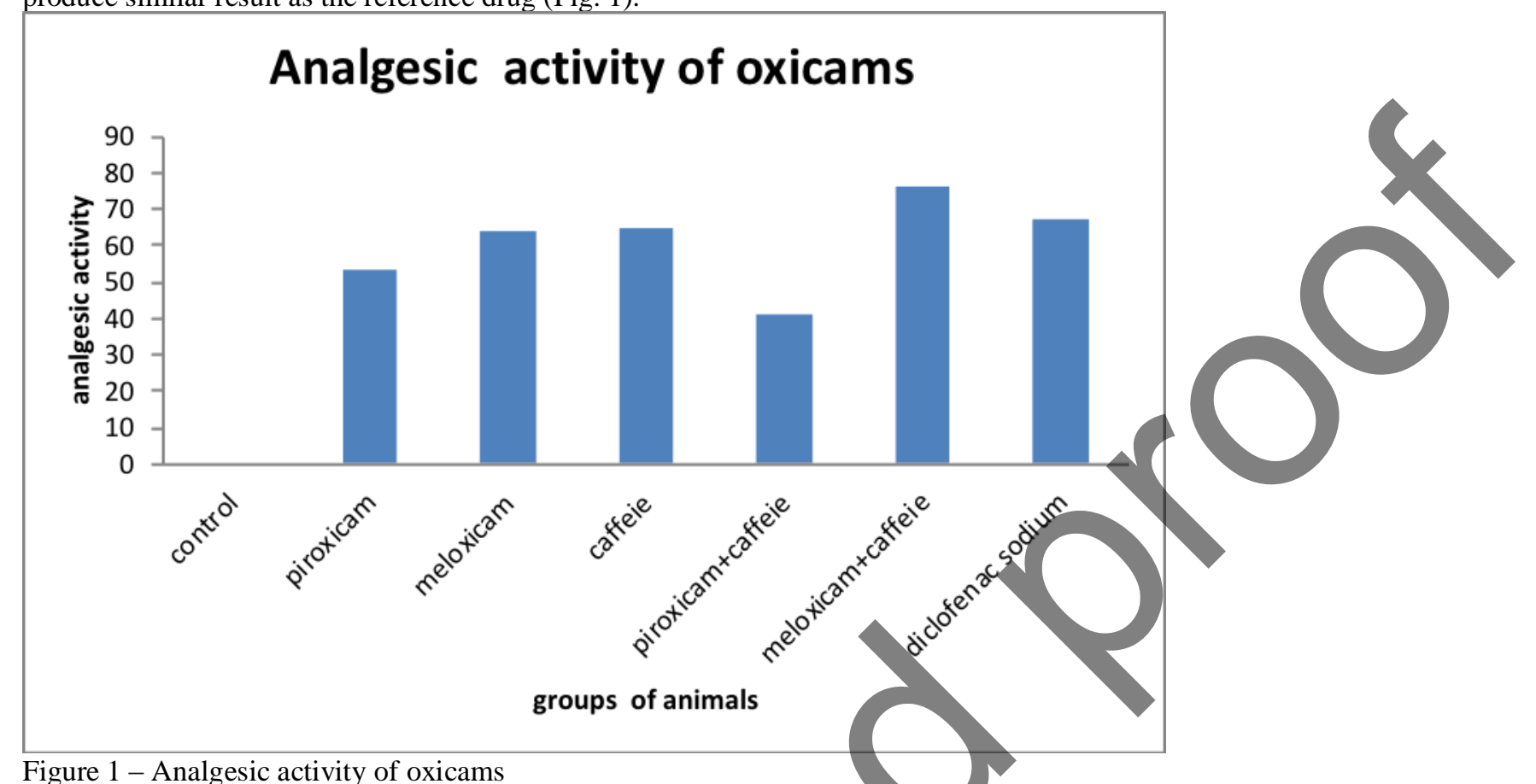

Figure 1 - Analgesic activity of oxicams

Such a result of caffeine peripheral analgesic activity may be associated with inhibition of the prostaglandins synthesis and TRPA1 channel, which acts as the main receptor neuropathic pain of peripheral origin. Caffeine also helps to eliminate exudate from the area of inflammation and, accordingly, reduces the compression of peripheral nociceptors. This is confirmed by our studies of the anti-exudative effect of above-mentioned compositions with caffeine ${ }^{13}$.

The analgesic activity of piroxicam $(53.6 \%)$ and caffeine $(64.5 \%)$ mono-preparations have similar value as reference drug - diclofenac sodium $(67.3 \%)$. Composition of piroxicam with caffeine shows the reduction of writhes by 1.7 and has the lowest value of analgesic activity $40.9 \%$. Piroxicam as a non-selective inhibitor of cyclooxygenase (COX-1 and COX-2) has a rapid and pronounced analgesic effect. The selectivity index (inhibition ratio $\mathrm{COX}-1 / \mathrm{COX}-2$ ) is 33, i.e. it has the highest potency against COX-1.However, literature review of nonselective NSAIDs effects indicates that the concomitant use of piroxicam with preparation having antiedemic action (caffeine) might reduce their effect. This effect could be attributed to the NSAID inhibition of renal prostaglandin synthesis and increased fluid retention. Coadministration of piroxicam with caffeine may show antagonism due to their pharmacokinetic properties. Additionally, the high affinity of caffeine to blood proteins could be a reason of antagonistic effect of this composition component on the peripheral analgesic effect $^{2}$.

The addition of caffeine to piroxicam facilitates mitigation of analgesic activity, so this composition shows unpromising results in relation to analgesic activity of the peripheral genesis. The opposite data was obtained by adding caffeine to meloxicam. The meloxicam and caffeine composition has the highest value of analgesic activity $76.4 \%$ and reduces number off writhes 4.2 times.

Meloxicam is a representative of the new generation of NSAIDs - selective COX-2 inhibitors. The selectivity index (inhibition ratio of COX-1/COX-2) is 0.33 ; it selectively inhibits the formation of prostaglandins involved in the formation of inflammation and has a much less effect on the synthesis of prostaglandins that regulate renal blood flow, production of protective mucus in the stomach and platelet aggregation. It is known, that selective COX-2 inhibitors doses in which selectivity is observed do not show a sufficient clinical effect. Increasing the dose leads to the loss of selectivity and the appearance of gastrotoxicity ${ }^{3}$.

Our research shows that meloxicam and its composition with caffeine in a lower dose $(0.6 \mathrm{mg})$ than piroxicam $(1.3 \mathrm{mg})$ and even reference drug $(8 \mathrm{mg})$ exhibit higher analgesic activity. The increased analgesic effect of meloxicam composition with caffeine could be explained by effect of caffeine on the bioavailability of meloxicam and synergetic effect of these two components. Results indicate potentiation of analgesic activity of the last one, therefore this composition is considered promising for further study (Table 1).

Table 1. The investigated peripheral analgesic activity of oxicams (meloxicam and piroxicam), caffeine and their pharmaceutical compositions with caffeine 


\begin{tabular}{|l|l|l|l|}
\hline № & Groups of animals & Number of writhes & Analgesic activity, \% \\
\hline 1 & Control & $22.00 \pm 0.856$ & - \\
\hline 2 & Piroxicam & $10.20 \pm 0.167^{1 / 3 / 4 / / 6 / 7}$ & 53.6 \\
\hline 3 & Meloxicam & $8.30 \pm 0.211^{1 / 2 / 5 / 6 / 7}$ & 63.6 \\
\hline 4 & Caffeine & $7.80 \pm 0.477^{1 / 2 / 5 / 6}$ & 64.5 \\
\hline 5 & Piroxicam + Caffeine & $13.00 \pm 0.365^{1 / 2 / 3 / 4 / 6 / 7}$ & 40.9 \\
\hline 6 & Meloxicam + Caffeine & $5.20 \pm 0.167^{1 / 2 / 3 / 4 / 5 / 7}$ & 76.4 \\
\hline 7 & Diclofenac sodium & $7.20 \pm 0.167^{1 / 2 / 3 / 5 / 6}$ & 67.3 \\
\hline
\end{tabular}

Note: difference is statistically significant:

1 - reliability of results in relation to the control group, $\mathrm{P}<0.05$;

${ }^{2}$-reliability of results with respect to the monopreparation of piroxicam, $\mathrm{P}<0.05$;

${ }^{3}$-reliability of results with respect to the monopreparation of meloxicam, $\mathrm{P}<0.05$;

${ }^{4}$ - reliability of results with respect to the monopreparation of caffeine, $\mathrm{P}<0.05$;

5 - reliability of results with respect to the composition of piroxicam with caffeine, $\mathrm{P}<0.05$;

6 - reliability of results with respect to the composition of meloxicam with caffeine, $\mathrm{P}<0.05$;

7 - reliability of results with respect to the monopreparation of diclofenac sodium, $\mathbf{P}<0.05$.

\section{CONCLUSIONS}

1. Meloxicam (dose: $0.6 \mathrm{mg} / \mathrm{kg}$ ) shows peripheral analgesic activity $(63.6 \%$ ) at the level of reference drug (diclofenac sodium) $(67.3 \%)$.

2. Meloxicam in the lowest dose $(0.6 \mathrm{mg} / \mathrm{kg})$ then piroxicam $(1.3 \mathrm{mg} / \mathrm{kg})$ demonstrates higher peripheral analgesic activity $63.6 \%$ and 53.6 correspondingly.

3. The peripheral analgesic activities of piroxicam $(53.6 \%)$ and caffeine $(64.5 \%)$ mono-preparations have higher values then their pharmaceutical composition (40.9\%). So, further study of the analgesic activity of piroxicam with caffeine composition is considered inexpedient.

4. Pharmacological composition of meloxicam with eaffeine demonstrated pain inhibition by $76.4 \%$, that significantly exceeded the peripheral analgesic activity of the reference drug - diclofenac sodium $67.3 \%$, i.e. caffeine effectively potentiates the analgesic activity of meloxicam. Thus, the composition of meloxicam with caffeine as a commercial source of a domestic analgesic drug could be subjected to further study.

\section{REFERENCES}

1. Laurence DR, Bennett PN Inflammation and non-steroidal anti-inflammatory drugs. 1991; 656:485-523.

2. Bilousov YuB. Clinical pharmacology and pharmacotherapy: A guide for physicians. 1997; 531.

3. Weir MR. Renal effects of nonselective NSAIDs and coxibs. Cleve Clin J Med. 2002; 69 Suppl 1(): SI53-8

4. Kozachok NN, Seluk MN., Bychkova SA. Optimalniy vibor nesteroidnogo protivivospalinelnogo preparata v sovremennoy klinicheskoy praktike. News of medicine and pharmacy. 2007. № 8 (218). 3-4.

5. Zupanets I.A., Nalotov S.V., Viktorov A.P., editors. Clinical pharmacology. Kharkov: NUPh; 2005.

6. Burchinsky SG. Clinical and pharmacological aspects of the choice of analgesic. Comparative analysis of the paracetamol effectiveness and safety. Pharmacologic Visnik. 2000; 354:12-17.

7. Nasonov EL. Nonsteroidal anti-inflammatory drugs: Prospects of use in medicine. Anko. 2000; 143:1-2.

8. Chekman I, Gorchakova N, Zvyagintseva T, Syrova G, Nebesna N. Coffeine: Physiological,

biochemical and quantum-pharmacological properties. Bulletin of Pharmacology and Pharmacy. 2009; 259:2-7.

9. Syrova GO, Zvyagintseva TV. Study of potentiating analgesic properties of caffeine in the experiment. XII Congress of the World Federation of Ukrainian Drug Societies; 2008 Sep 25 v28; Ivano-Frankivsk, 2008. p.

10. Sawynok, J, Caffeine and pain. 2011 152: 726-729

Sawynok J, Yaksh TL. Caffeine as an analgesic adjuvant: a review of pharmacology and mechanisms of action. Pharmacological Reviews. 1993, 45 (1): 43-85

Fisone G, Borgkvist A, Usiello A. Caffeine as a psychomotor stimulant: mechanism of action. Cellular and Molecular Life Sciences. 2004, 61: 857-872

13. Syrova GO, Lukianova LV, Chalenko NM. The experimental research on the antiinflammatory action of the new piroxicam-caffeine pharmaceutical composition. Science Review. 2018, 4, № 3(10). 72-76.

14. Stefanov O.V., editor. Preclinical research of medicines: methodological recommendations. Kiiv: Avicenna; 2001. p. 431-432. 
15. Trinus FP, Klebanov BM, Kondratyuk VI., editors. Methodical recommendations for the experimental (preclinical) study of non-steroidal anti-inflammatory pharmacological substances. Moskow; 1983.

16. Burkatskaya EN, Beyer VF., editors. Methodical recommendations on the use of behavioral reactions of animals in toxicological studies. Kiev; 1980. p. 47.

17. European convention for the protection of vertebrate animals used for experimental and other scientific purposes: Council of European. Strasbourg, 1986; 51:29-34.

18. Kundiev Yu.I., editor. Modern problems of bioethics. Kiev: Akademperiodica, 2009; 278:141-173.

19. Drogovoz SM, Rapoport SI, Kononenko AV. Informative chronopharmacology (chronopharmacology in tables and figures): a textbook. Kharkov: Titule; 2014. 128:111-117.

20. Dorogoy AP. To the question of chronopathology, chronotherapy and chronopharmacology in cardiology: Actual problems in modern therapy. Kharkiv; 1992. 354:22-25.

21. Zapadnyuk IP, Zapadnyuk VI, Zakharia EA. Laboratory animals: breeding, content, use in experiment. $3^{\text {rd }}$ ed., Revised. and additional. Kiev: Vishcha sckola. Head Publishing House; 1983. 383:141-154.

22. Glanc S. Medico-biological statistics. Moscow: Practica; 1998. 459: 318-323. 